Article

\title{
Cinara splendens (Hemiptera: Aphididae: Lachninae)—First Record in Palaearctic Region
}

\author{
Jan Havelka ${ }^{1, *}$, Jekaterina Havelka ${ }^{2}$ and Petr Starý ${ }^{1}$ \\ 1 Institute of Entomology, Biology Centre CAS, Branišovská 31, 37001 České Budějovice, Czech Republic; \\ stary@entu.cas.cz \\ 2 Institute of Biosciences, Life Sciences Centre, Vilnius University, Saulètekio al. 7, LT-10257 Vilnius, Lithuania; \\ jekaterina.havelka@gf.vu.lt \\ * Correspondence: jhav@entu.cas.cz; Tel.: +420-728-892-694
}

Received: 25 July 2020; Accepted: 18 August 2020; Published: 20 August 2020

check for updates

\begin{abstract}
Nearctic aphid Cinara splendens (Gillette and Palmer, 1924) was collected on ornamental Douglas fir (Pseudotsuga menziesii (Mirb.) Franco) in South Bohemia in 2009. It was the first record of this species in the Palaearctic region. The aim of this research was to study the bionomy of this species in Central Europe and to make descriptions of all available morphs, as previous morphological descriptions of C. splendens appeared to be incomplete. Six monitoring sites of this species were established in South Bohemia and were then regularly attended in the period of 2009-2019. The colonies of C. splendens were observed; its natural enemies and honeydew users were also registered. Aphids were collected for the microscope slide preparation, followed by the evaluation of thirty of the basic quantitative and seven qualitative morphological characteristics. Partial sequences of mitochondrial COI and nuclear EF- $1 \alpha$ were used to confirm morphology-based identification and to compare samples from the Czech Republic with those of North American origin. Cinara splendens survived successfully under new ecological conditions, but its population density remained quite low, except for 2009 and 2019, due to a synergistic effect of the dry weather and very high population density of the adelgid Gilletteella coweni (Gillette, 1907), which is a key pest of Douglas fir in the Czech Republic. The principle predators were coccinellid beetles, while the aphidophagous hover flies were less abundant. Together with a weak ability to migrate due to a low number of alate viviparous females in population, C. splendens cannot be a potential pest of P. menziesii in Central Europe.
\end{abstract}

Keywords: Cinara splendens; Pseudotsuga menziesii; exotic aphid species; bionomy; natural enemies; mitochondrial COI; nuclear EF-1 $\alpha$

\section{Introduction}

There have been an increasing number of alien aphid species in Europe in recent decades [1-8], in particular aphids on economic and ornamental plants of foreign origin. Douglas fir (Pseudotsuga menziesii (Mirb.) Franco) attracts the attention of experts as a beautiful decorative plant and as a prospective production tree species in forestry. Pseudotsuga menziesii was introduced from North America into Great Britain in 1827. Later (in 1827) it was planted in the Hamburg Arboretum. The species offers tremendous economic potential $[9,10]$, and will likely become even more widely planted in southwestern Germany in the coming decades as a substitute for Norway spruce (Picea abies (L.) Karst.), which appears to be seriously threatened by climate change [11]. A series of experiments were set up at the turn of the century (e.g., [12]) to explore the potential value of growing. Currently, Douglas fir is by far the most widely planted exotic tree in Baden-Württemberg, covering about 38,000 hectares and representing approximately $3 \%$ of the state's forest area [13]. Similar experiments 
have been started in the Czech Republic (in 1971), where Douglas fir is currently cultivated in an area of 5818 hectares [14].

The key pests of North American Douglas fir in Europe are wooly conifer aphids of the genus Gilletteella, G. cooleyi (Gillette, 1907) and G. coweni (Gillette, 1907). In 2009, during the regular sampling of the colonies of G. coweni, we found an unknown species of Cinara on the model trees P. menziesii in park localities in České Budějovice (South Bohemia). These aphids produced small colonies on the two-year-old twigs among the needles. Microscopic and partial DNA sequence analysis of the samples revealed that this aphid species was the strictly monophagous Cinara splendens (Gillette and Palmer, 1924) of North American origin. The apterous parthenogenetic females, as well as the larvae of $C$. splendens, are covered with a thick layer of white wax, so in wax-covered colonies of Gilleteella adelgid they completely escaped attention. Mimicry of the $C$. splendens enforces the fact that on the infested branches, the ants, which are a characteristic part of the trophic relations in almost all aphids of the family Lachnidae, were completely absent.

The aim of this research was to study the bionomy of this species in Central Europe and to make the descriptions of all available morphs, as previous morphological description of $C$. splendens appeared to be incomplete.

\section{Materials and Methods}

After finding the first colonies of the C. splendens, the infestation of $P$. menziesii trees was examined at other localities. Two model localities (Stráž nad Nežárkou and Č. Budějovice) and 1 and 5 groups of model trees, respectively, were established. Furthermore, on the model trees, the life cycle was studied and natural enemies of an invasive species were collected in new conditions. Control of the model trees was carried out regularly, every 3 weeks during the growing season. Aphid material for microscopic analysis was collected only occasionally and samples are listed in Table 1.

Apterous and alate viviparous females were dropped onto a surface of a special plate held beneath an infested plant, and the aphids were put into tubes with $85 \%$ ethanol by means of a paintbrush. Moreover, the parts of host plants with aphid colonies were cut off by a trimmer and placed in the plastic bags. Aphids finished their preimaginal development within a few days and then were transferred into storage fluid. Aphids' natural enemies were kept in Petri dishes with plant material to breed adults of predators or parasitoids. Environmental data were registered.

Aphid samples stored in labeled tubes were degreased, macerated, cleared and mounted onto the slide by standard procedure later in the laboratory. Gum-chloral hydrate (Faure-Berlese's fluid) or Canada balsam in xylene was used as mounting fluid. After the aphids were identified, the slides were labeled and used for reference collection.

A series of individuals were used for measurements: 8 fundatrices, 34 apterous viviparous females, 22 alate viviparous females, 7 males and 21 oviparae. In total, 30 of the basic quantitative and 7 qualitative morphological characters were evaluated at different magnifications under the microscope Olympus BX41 (see Table S1 for details). Species identification was done using keys of Palmer [15] and Blackman and Eastop [16] and its latest internet version on http://www.aphidsonworldsplants. info/ (2018). To check the correctness of the microscopic species determination, partial DNA sequences were analyzed. 
Table 1. Microscopic slides of Cinara splendens (Gillette and Palmer, 1924) collected in South Bohemia from Pseudotsuga menziesii (Mirb.) Franco. Legend: $\mathrm{fx}=$ fundatrix; aptvf = apterous viviparous female; alvf = alate viviparous female.

\begin{tabular}{|c|c|c|c|c|}
\hline No. of Sample & Locality & GPS & Date & Aphid Morph \\
\hline 09НА3366 & Č. Budějovice, Destinové str. & $48^{\circ} 58^{\prime} 49.9^{\prime \prime} \mathrm{N} 14^{\circ} 26^{\prime} 57.0^{\prime \prime} \mathrm{E}$ & 2009-04-25 & fx, aptvf \\
\hline 09НА3367 & Č. Budějovice, Destinové str. & $48^{\circ} 58^{\prime} 49.9^{\prime \prime} \mathrm{N} 14^{\circ} 26^{\prime} 57.0^{\prime \prime} \mathrm{E}$ & 2009-04-25 & $f x$, aptvf \\
\hline 09НА3369 & Č. Budějovice, J. Opletala str. & $48^{\circ} 58^{\prime} 51.3^{\prime \prime} \mathrm{N} 14^{\circ} 26^{\prime} 44.1^{\prime \prime} \mathrm{E}$ & 2009-04-25 & fx, aptvf \\
\hline 09НА3377 & Stráž nad Nežárkou & $49^{\circ} 04^{\prime} 10.7^{\prime \prime} \mathrm{N} 14^{\circ} 54^{\prime} 08.1^{\prime \prime} \mathrm{E}$ & 2009-04-27 & $f x$, aptvf \\
\hline 09НА3376 & Stráž nad Nežárkou & $49^{\circ} 04^{\prime} 10.7^{\prime \prime} \mathrm{N} 14^{\circ} 54^{\prime} 08.1^{\prime \prime} \mathrm{E}$ & 2009-04-27 & $\mathrm{fx}$, aptvf \\
\hline 09НА3501 & Stráž nad Nežárkou & $49^{\circ} 04^{\prime} 10.7^{\prime \prime} \mathrm{N} 14^{\circ} 54^{\prime} 08.1^{\prime \prime} \mathrm{E}$ & 2009-05-25 & aptvf \\
\hline 09НА3502 & Stráž nad Nežárkou & $49^{\circ} 04^{\prime} 10.7^{\prime \prime} \mathrm{N} 14^{\circ} 54^{\prime} 08.1^{\prime \prime} \mathrm{E}$ & 2009-05-25 & aptvf \\
\hline 09НА3503 & Stráž nad Nežárkou & $49^{\circ} 04^{\prime} 10.7^{\prime \prime} \mathrm{N} 14^{\circ} 54^{\prime} 08.1^{\prime \prime} \mathrm{E}$ & 2009-05-25 & aptvf \\
\hline 09НА3504 & Praha 6, Břevnov park & $50^{\circ} 05^{\prime} 05.4^{\prime \prime} \mathrm{N} 14^{\circ} 22^{\prime} 03.4^{\prime \prime} \mathrm{E}$ & 2009-05-30 & aptvf \\
\hline 09НА3546 & Stráž nad Nežárkou & $49^{\circ} 04^{\prime} 10.7^{\prime \prime} \mathrm{N} 14^{\circ} 54^{\prime} 08.1^{\prime \prime} \mathrm{E}$ & 2009-06-15 & aptvf \\
\hline 09НА3989 & Stráž nad Nežárkou & $49^{\circ} 04^{\prime} 10.7^{\prime \prime} \mathrm{N} 14^{\circ} 54^{\prime} 08.1^{\prime \prime} \mathrm{E}$ & 2009-10-07 & aptvf \\
\hline 09HA4027 & Č. Budějovice, Mariánské square & $48^{\circ} 58^{\prime} 46.5^{\prime \prime} \mathrm{N} 14^{\circ} 28^{\prime} 22.0^{\prime \prime} \mathrm{E}$ & 2009-11-10 & male, ovipara \\
\hline 09НА4043 & Č. Budějovice, Mariánské square & $48^{\circ} 58^{\prime} 46.5^{\prime \prime} \mathrm{N} 14^{\circ} 28^{\prime} 22.0^{\prime \prime} \mathrm{E}$ & 2009-11-10 & male, ovipara \\
\hline 11HA4255 & Č. Budějovice, Mariánské square & $48^{\circ} 58^{\prime} 46.5^{\prime \prime} \mathrm{N} 14^{\circ} 28^{\prime} 22.0^{\prime \prime} \mathrm{E}$ & 2011-04-28 & $\mathrm{fx}$, aptvf \\
\hline 11HA4256 & Č. Budějovice, Mariánské square & $48^{\circ} 58^{\prime} 46.5^{\prime \prime} \mathrm{N} 14^{\circ} 28^{\prime} 22.0^{\prime \prime} \mathrm{E}$ & 2011-04-28 & $f x$, aptvf \\
\hline 12HA4549 & Stráž nad Nežárkou & $49^{\circ} 04^{\prime} 10.7^{\prime \prime} \mathrm{N} 14^{\circ} 54^{\prime} 08.1^{\prime \prime} \mathrm{E}$ & 2012-06-20 & aptvf \\
\hline 13НA4682 & Č. Budějovice, Stromovka-park & $48^{\circ} 58^{\prime} 09.4^{\prime \prime} \mathrm{N} 14^{\circ} 27^{\prime} 17.7^{\prime \prime} \mathrm{E}$ & 2013-10-10 & aptvf \\
\hline 15HA4669 & Č. Budějovice, Destinové str. & $48^{\circ} 58^{\prime} 49.9^{\prime \prime} \mathrm{N} 14^{\circ} 26^{\prime} 57.0^{\prime \prime} \mathrm{E}$ & $2015-05-25$ & aptvf, alvf \\
\hline 15HA4670 & Č. Budějovice, Destinové str. & $48^{\circ} 58^{\prime} 49.9^{\prime \prime} \mathrm{N} 14^{\circ} 26^{\prime} 57.0^{\prime \prime} \mathrm{E}$ & $2015-05-25$ & aptvf, alvf \\
\hline 15HA4671 & Č. Budějovice, Destinové str. & $48^{\circ} 58^{\prime} 49.9^{\prime \prime} \mathrm{N} 14^{\circ} 26^{\prime} 57.0^{\prime \prime} \mathrm{E}$ & 2015-05-25 & aptvf, alvf \\
\hline 15HA4775 & Č. Budějovice, Destinové str. & $48^{\circ} 58^{\prime} 49.9^{\prime \prime} \mathrm{N} 14^{\circ} 26^{\prime} 57.0^{\prime \prime} \mathrm{E}$ & 2015-05-25 & aptvf, alvf \\
\hline 15HA4781 & Č. Budějovice, Destinové str. & $48^{\circ} 58^{\prime} 49.9^{\prime \prime} \mathrm{N} 14^{\circ} 26^{\prime} 57.0^{\prime \prime} \mathrm{E}$ & 2015-05-25 & aptvf, alvf \\
\hline 15HA4782 & Č. Budějovice, Destinové str. & $48^{\circ} 58^{\prime} 49.9^{\prime \prime} \mathrm{N} 14^{\circ} 26^{\prime} 57.0^{\prime \prime} \mathrm{E}$ & 2015-05-25 & aptvf, alvf \\
\hline 15HA4783 & Č. Budějovice, Destinové str. & $48^{\circ} 58^{\prime} 49.9^{\prime \prime} \mathrm{N} 14^{\circ} 26^{\prime} 57.0^{\prime \prime} \mathrm{E}$ & $2015-05-25$ & aptvf, alvf \\
\hline 16НA5106 & Č. Budějovice, Stromovka park & $48^{\circ} 58^{\prime} 09.4^{\prime \prime} \mathrm{N} 14^{\circ} 27^{\prime} 17.7^{\prime \prime} \mathrm{E}$ & 2016-11-11 & male \\
\hline 16НA5107 & Č. Budějovice, Stromovka park & $48^{\circ} 58^{\prime} 09.4^{\prime \prime} \mathrm{N} 14^{\circ} 27^{\prime} 17.7^{\prime \prime} \mathrm{E}$ & 2016-11-11 & male \\
\hline 16НA5108 & Č. Budějovice, Stromovka-park & $48^{\circ} 58^{\prime} 09.4^{\prime \prime} \mathrm{N} 14^{\circ} 27^{\prime} 17.7^{\prime \prime} \mathrm{E}$ & 2016-11-11 & ovipara \\
\hline 16НA5109 & Č. Budějovice, Stromovka park & $48^{\circ} 58^{\prime} 09.4^{\prime \prime} \mathrm{N} 14^{\circ} 27^{\prime} 17.7^{\prime \prime} \mathrm{E}$ & 2016-11-11 & ovipara \\
\hline 16НA5110 & Č. Budějovice, Stromovka park & $48^{\circ} 58^{\prime} 09.4^{\prime \prime} \mathrm{N} 14^{\circ} 27^{\prime} 17.7^{\prime \prime} \mathrm{E}$ & 2016-11-11 & ovipara \\
\hline 16НA5110 & Č. Budějovice, Šumava distr. & $48^{\circ} 58^{\prime} 89.3^{\prime \prime} \mathrm{N} 14^{\circ} 07^{\prime} 66.4^{\prime \prime} \mathrm{E}$ & 2016-06-16 & aptvf, alvf \\
\hline 19HА5939 & Č. Budějovice, Stromovka park & $48^{\circ} 58^{\prime} 09.4^{\prime \prime} \mathrm{N} 14^{\circ} 27^{\prime} 17.7^{\prime \prime} \mathrm{E}$ & 2019-01-25 & eggs \\
\hline 19HA5445 & Č. Budějovice, Šumava distr. & $48^{\circ} 58^{\prime} 89.3^{\prime \prime} \mathrm{N} 14^{\circ} 07^{\prime} 66.4^{\prime \prime} \mathrm{E}$ & 2019-06-06 & aptvf, alvf \\
\hline 19HA5448 & Č. Budějovice, Šumava distr. & $48^{\circ} 58^{\prime} 89.3^{\prime \prime} \mathrm{N} 14^{\circ} 07^{\prime} 66.4^{\prime \prime} \mathrm{E}$ & 2019-06-06 & aptvf, alvf \\
\hline 19HA5450 & Č. Budějovice, Šumava distr. & $48^{\circ} 58^{\prime} 89.3^{\prime \prime} \mathrm{N} 14^{\circ} 07^{\prime} 66.4^{\prime \prime} \mathrm{E}$ & 2019-06-06 & aptvf, alvf \\
\hline 19HA5451 & Č. Budějovice, Šumava distr. & $48^{\circ} 58^{\prime} 89.3^{\prime \prime} \mathrm{N} 14^{\circ} 07^{\prime} 66.4^{\prime \prime} \mathrm{E}$ & 2019-06-06 & aptvf, alvf \\
\hline 19HA5452 & Č. Budějovice, Šumava distr. & $48^{\circ} 58^{\prime} 89.3^{\prime \prime} \mathrm{N} 14^{\circ} 07^{\prime} 66.4^{\prime \prime} \mathrm{E}$ & 2019-06-06 & aptvf, alvf \\
\hline 19HA5454 & Č. Budějovice, Šumava distr. & $48^{\circ} 58^{\prime} 89.3^{\prime \prime} \mathrm{N} 14^{\circ} 07^{\prime} 66.4^{\prime \prime} \mathrm{E}$ & 2019-06-06 & aptvf, alvf \\
\hline
\end{tabular}

Total genomic DNA was extracted from a single aphid using DNeasy Blood and Tissue kit (Qiagen). The following primer pairs were used for the amplification: LCO-1490 and HCO-2198 for COI [17], and EF3 and EF6 for EF-1 $\alpha$ [18]. PCR amplification was carried out in a thermal cycler (Eppendorf) in $50 \mu \mathrm{L}$ volumes containing $2 \mu \mathrm{L}$ of genomic DNA, $2.5 \mu \mathrm{L}$ of each primer $(0.5 \mu \mathrm{M}), 25 \mu \mathrm{L}$ of DreamTaq PCR master mix (Thermo Scientific) and $18 \mu \mathrm{L}$ of nuclease-free water (Thermo Scientific). The cycling parameters were as follows: denaturizing at $95^{\circ} \mathrm{C}$ for $5 \mathrm{~min}(1 \mathrm{cycle})$, denaturizing at $95^{\circ} \mathrm{C}$ for $1 \mathrm{~min}$, annealing at $47^{\circ} \mathrm{C}(\mathrm{COI})$ or $50^{\circ} \mathrm{C}(\mathrm{EF}-1 \alpha)$ for $30 \mathrm{~s}$, extension at $72{ }^{\circ} \mathrm{C}$ for $2 \mathrm{~min}$ ( 35 cycles in total), and final extension at $72^{\circ} \mathrm{C}$ for $10 \mathrm{~min}$ ( 1 cycle). PCR products were subjected to electrophoresis on $2 \%$ TopVision agarose (Thermo Scientific), stained with ethidium bromide and sized against MassRuler Express Forward DNA ladder (Thermo Scientific) under UV light. PCR products were purified with a Gene Jet PCR purification kit (Thermo Scientific) and sequenced at Macrogen Europe (Amsterdam, the Netherlands). The amplification primers were also used as sequencing primers. DNA sequences were aligned in the BioEdit Sequence Alignment Editor [19]. Additional sequences for comparison were downloaded from GenBank (Table 2). Neighbor-joining (NJ) trees were constructed to examine relationships among taxa and population samples and MEGA 7 [20] was used for this procedure. 
Table 2. Partial COI and EF-1 $\alpha$ sequences of Cinara spp. from Pseudotsuga spp.

\begin{tabular}{|c|c|c|c|c|}
\hline $\begin{array}{c}\text { Voucher } \\
\text { [Reference] }\end{array}$ & Host Species & Location & $\begin{array}{l}\text { GenBank Accession no. } \\
\text { COI Fragment }\end{array}$ & $\begin{array}{c}\text { GenBank Accession no. } \\
\text { EF-1 } \alpha \text { Fragment }\end{array}$ \\
\hline \multicolumn{5}{|c|}{ Cinara pseudotaxifoliae } \\
\hline $2917[21]$ & Pseudotsuga sp. & New-Mexico (US) & KF649448 & KF693924 \\
\hline 2919 [21] & Pseudotsuga sp. & New-Mexico (US) & KF649450 & KF693926 \\
\hline $2981[21]$ & Pseudotsuga sp. & California (US) & KF649478 & KF693950 \\
\hline $3029[21]$ & Pseudotsuga sp. & Washington (US) & KF649506 & KF693978 \\
\hline $3047[21]$ & Pseudotsuga sp. & Oregon (US) & KF649516 & KF693988 \\
\hline 3056 [21] & Pseudotsuga sp. & Oregon (US) & KF649523 & KF693995 \\
\hline $3076[21]$ & Pseudotsuga sp. & California (US) & KF649539 & KF694010 \\
\hline $2921[21]$ & Abies sp. & New-Mexico (US) & KF649452 & KF693928 \\
\hline 3407 [22] & Pseudotsuga menziesii & - & KY064238 & KY064492 \\
\hline 3363 [22] & Pseudotsuga menziesii & - & KY064202 & KY064458 \\
\hline 3343 [22] & Pseudotsuga menziesii & - & KY064191 & KY064446 \\
\hline \multicolumn{5}{|c|}{ Cinara pseudotsugae } \\
\hline $2881[21]$ & Pseudotsuga sp. & Colorado (US) & KF649415 & - \\
\hline 2889 [21] & Pseudotsuga sp. & Colorado (US) & KF649422 & KF693905 \\
\hline 2918 [21] & Pseudotsuga sp. & New-Mexico (US) & KF649449 & KF693925 \\
\hline 2915bis [21] & Pseudotsuga sp. & New-Mexico (US) & KF649446 & KF693923 \\
\hline $2890[21]$ & Pseudotsuga sp. & Colorado (US) & KF649423 & KF693906 \\
\hline \multicolumn{5}{|c|}{ Cinara splendens } \\
\hline $2987[21]$ & Pseudotsuga sp. & California (US) & KF649483 & KF693954 \\
\hline
\end{tabular}

\section{Results}

Mounted apterous viviparous females of Cinara sp. from P. menziesii collected in the Czech Republic were identified as Cinara splendens following the key given below (Figures 1 and 2).

The key to the Cinara species on Pseudotsuga menziesii (Mirb.) Franco in the North America given below is from http://www.aphidsonworldsplants.info/C_HOSTS_Psa_Pyr.htm\#Pseudotsuga.

1. Siphunculi pores on broad pigmented conical bases $0.4 \mathrm{~mm}$ or more in diameter. (Antennal hairs numerous, $0.08 \mathrm{~mm}$ or more long; hind tibial hairs $0.10-0.15 \mathrm{~mm}$ long). - Cinara (Cinara) commatula.

- Siphunculi cones very small, with pigmented area less than $0.2 \mathrm{~mm}$ in diameter. -2

2. All tibiae almost wholly pale, except that hind tibiae have contrastingly black apices. - Cinara (Cinara) splendens.

- At least hind tibia dark or shading to dark over distal third or more of length. -3

3. Longest abdominal hairs more than $0.10 \mathrm{~mm}$ long, longer than hairs on dorsal side of hind tibia, which are about $0.08 \mathrm{~mm}$ long. - Cinara (Cinara) vagabunda.

- Longest abdominal hairs less than $0.10 \mathrm{~mm}$ long or, if longer, then they are shorter than longest hairs on dorsal side of hind tibia. -4

4. Longest hairs on dorsal side of hind tibia $0.09-0.16 \mathrm{~mm}$. length of sclerotised part of stylet groove 0.8-1.0 mm. - Cinara (Cinara) pseudotsugae. 
- Longest hairs on dorsal side of hind tibia $0.050-0.075 \mathrm{~mm}$. length of sclerotised part of stylet groove 1.1-1.5 mm. - Cinara (Cinara) pseudotaxifoliae.

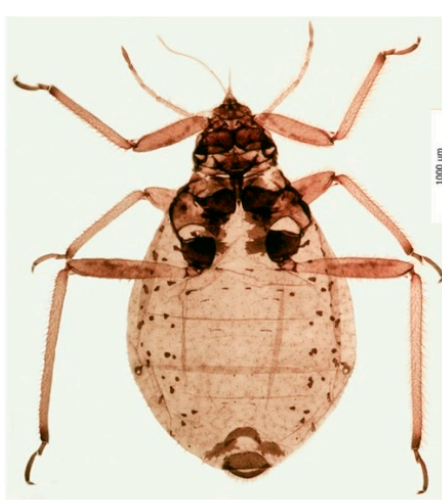

A

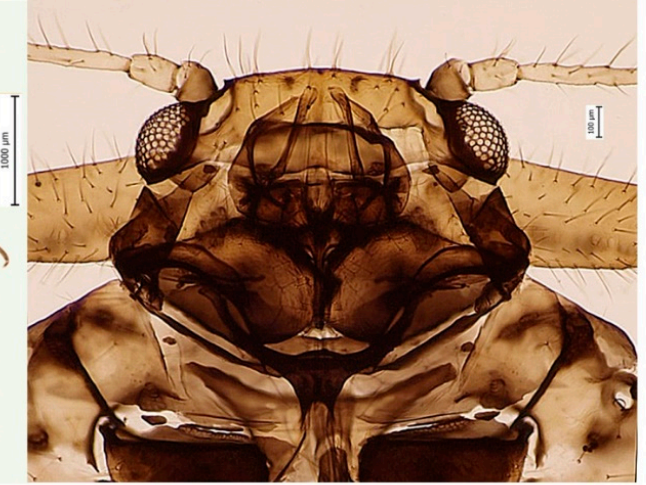

B
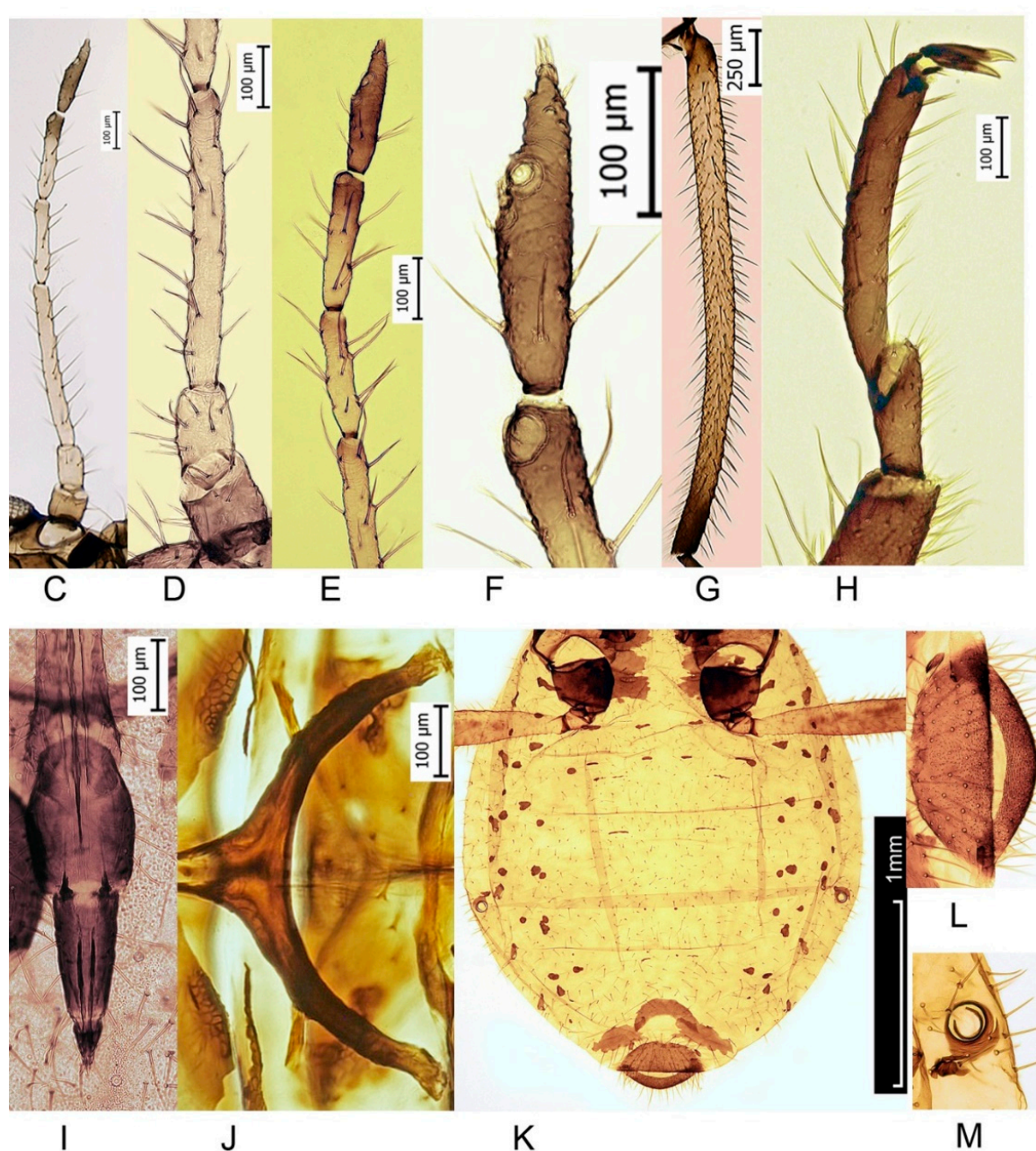

$\mathrm{K}$

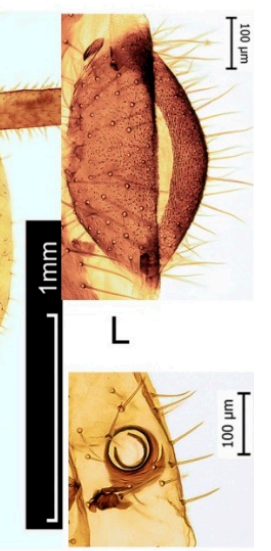

$\mathrm{M}$

Figure 1. Cinara splendens (Gillette and Palmer, 1924) apterous viviparous female. (A) Whole body; (B) head; (C) antenna; (D) 1st-3rd segments of antenna; (E) 4th-6th segments of antenna; (F) 6th segment of antenna; (G) hind tibia; (H) hind tarsus; (I) 4th + 5th segments of rostrum; (J) furca of the mesothotax; (K) abdomen; (L) cauda; (M) siphunculus. 


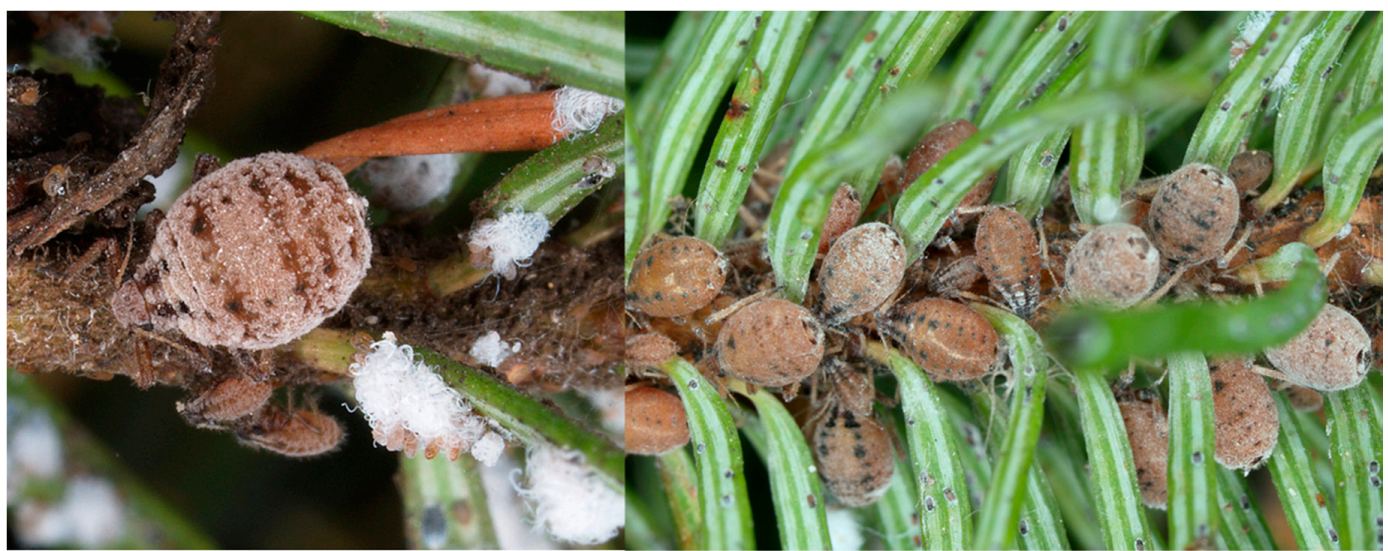

A

B

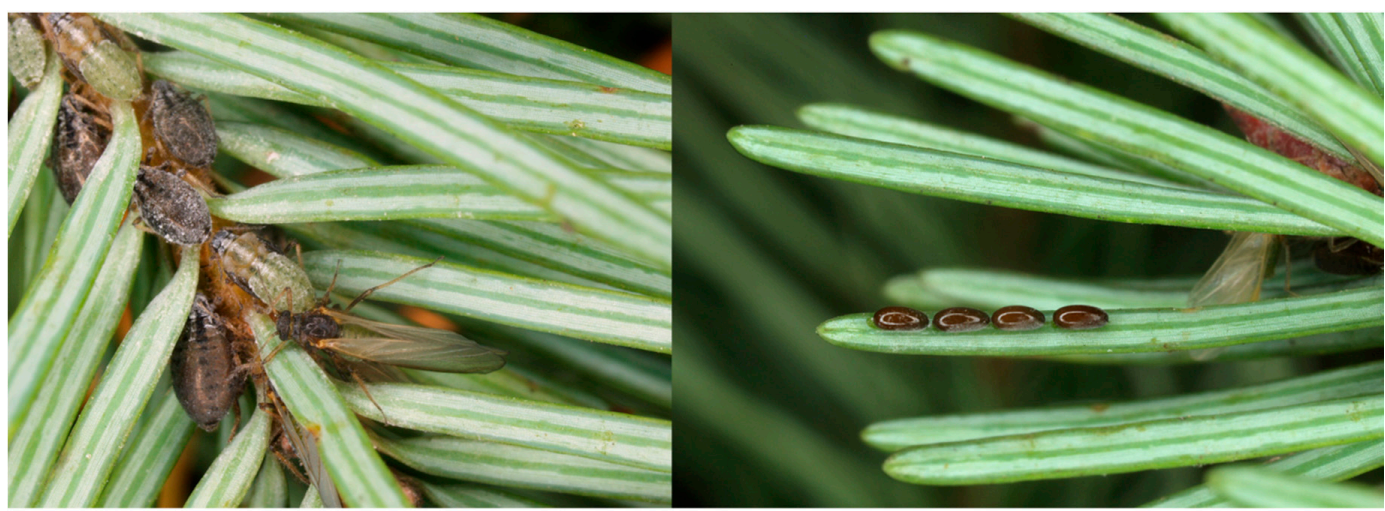

C

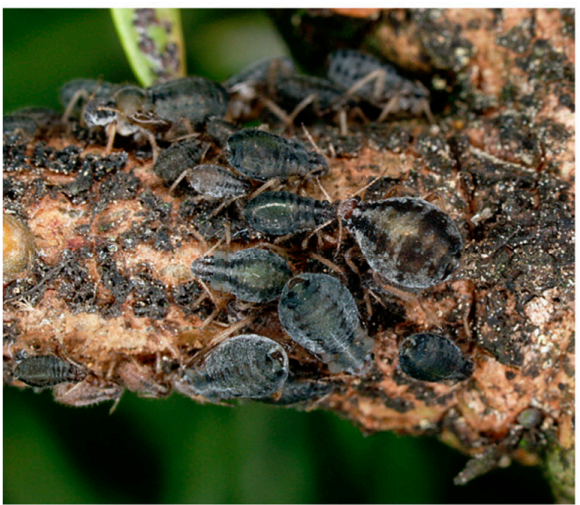

$E$

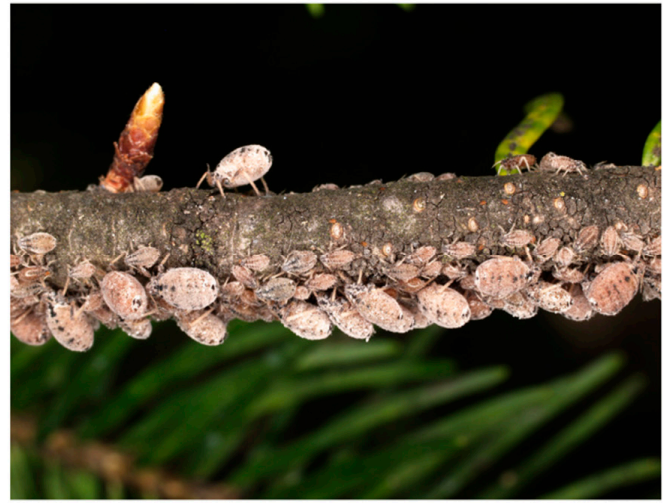

$\mathrm{F}$

Figure 2. Cinara splendens (Gillette and Palmer, 1924). (A) Apterous viviparous female; (B) colony of apterous viviparous females; (C) oviparae, alate males and male nymphs; (D) eggs on needles of the Pseudotsuga mensiesii (Mirb.) Franko; (E) fundatrix; (F) damage of Douglas fir by Cinara and Gilletteella.

The original description of $C$. splendens as well as bionomy appeared to be incomplete. Therefore, here we present the main data concerning the morphology and average values of some quantitative characters of this species, based on samples collected in the Czech Republic (see the Table S1 in Supplementary Material for details). 
A fundatrix is a wingless viviparous female. It differs from the apterous viviparous females of the summer generations only by its slightly larger abdomen, less intensive wax powder, darker color and shorter appendages. The body length is $3.7 \mathrm{~mm}$.

An apterous viviparous female is light brown or yellowish brown, strongly powdered with wax making a pattern of transverse stripes, with two darker longitudinal dorsal stripes without wax diverging from thorax posteriorly (Figure 2). The abdomen has two more weakly distinct longitudinal bands on the abdominal segments; the siphuncular cones are black, very small; legs yellowish, with dark brown distal ends of tibiae. The antenna is six segmented, $1.16 \mathrm{~mm}$ (0.10:0.10:0.38:0.19:0.21:0.18). The basal part of the last antennal segment VI (VIa) is about twice as long as processus terminalis (VIb). The processus terminalis has four subapical hairs, while VIa has six hairs confined to the basal half. The primary rhinarium on segment VI has a ring of small sclerites. The rostrum is short $(0.98 \mathrm{~mm})$ and the ultimate rostrum segments are $0.2 \mathrm{~mm}$, with $4-5$ accessory hairs. The ventral side of the first segment of hind tarsus is $0.14 \mathrm{~mm}$, the dorsal side is $0.07 \mathrm{~mm}$, the inter-tarsal side is $0.06 \mathrm{~mm}$, and the basal side is $0.05 \mathrm{~mm}$. The second segment of hind tarsus (hts2) is $0.32 \mathrm{~mm}$. The diameter of siphuncular sclerite (cone) is about $0.09 \mathrm{~mm}$. Hairs on the abdomen are numerous, fine, up to about $0.09 \mathrm{~mm}$. The body length is $3.4 \mathrm{~mm}$.

An alate viviparous female is much like the apterous viviparous female. The third antennal segment is $0.5 \mathrm{~mm}$ long with $5-7$ secondary rhinaria. Body length is $3.0 \mathrm{~mm}$.

An oviparous female is similar to the apterous viviparous female and is brown, with a weak wax-covering. The pericaudal wax ring is absent (Figure 2). The hind tibia is slightly thickened from base to apex, with more than 100 small scent plaques. The hairs on the hind tibia are $0.12 \mathrm{~mm}$, while the hairs on third abdominal segment are $0.07 \mathrm{~mm}$ long. The ventral side of the first segment of hind tarsus is $0.14 \mathrm{~mm}$, dorsal side is $0.07 \mathrm{~mm}$, intertarsal side is $0.06 \mathrm{~mm}$, basal side is $0.05 \mathrm{~mm}$. Body length is $3.3 \mathrm{~mm}$.

An alate male's body is oblong-oval, light green color (Figure 2), with two darker longitudinal dorsal stripes. The body length is $2.5 \mathrm{~mm}$. The antenna is $1.4 \mathrm{~mm}$, light brown in color with long hairs $(0.1 \mathrm{~mm})$. The third antennal segment is $0.5 \mathrm{~mm}$ long with $42-52$ secondary rhinaria, the fourth antennal segment is $0.2 \mathrm{~mm}$ long with 11-16 secondary rhinaria, and the fifth antennal segment is $0.3 \mathrm{~mm}$ long with 9-12 secondary rhinaria. The hind tibia is $1.6 \mathrm{~mm}$ long, light brown, with long $(0.14 \mathrm{~mm})$, dense hairs. The hairs on the third abdominal segment are $0.08 \mathrm{~mm}$ long. The ventral side of the first segment of hind tarsus is $0.11 \mathrm{~mm}$, the dorsal side is $0.07 \mathrm{~mm}$, the inter-tarsal side is $0.05 \mathrm{~mm}$, and the basal side is $0.07 \mathrm{~mm}$.

The whole life cycle of C. splendens in the Czech Republic is presented in Figure 3. There were probably seven generations during the season, depending mainly on mean temperature. Cinara splendens overwinters as eggs, usually in groups of four on needles. Fundatrices hatch in the middle of April in the Czech Republic. The second generation consists of apterous viviparous females occurring from the end of May until the end of June. The percentage of alate viviparous females in the colonies depends on the host plant's physiological condition, influenced primarily by dry weather and the presence of dense G. coweni colonies. At those stress conditions, about $50 \%$ of winged partenogentic females appear already in the third generation between June and early July. Around mid-July until the end of September, C. splendens practically disappears from the branches of $P$. menziesii, probably due to migration to the roots of its host tree. This phenomenon is also common in other Cinara species, such as Cinara confinis (Koch, 1856), Cinara kochiana (Börner, 1939), Cinara mordvilkoi (Pašek, 1954) and Cinara curvipes (Patch, 1912). Therefore, except from four generations observed on the branches of $P$. menziesii, there may be at least three generations during the summer hiding under the ground or next to the ground. 


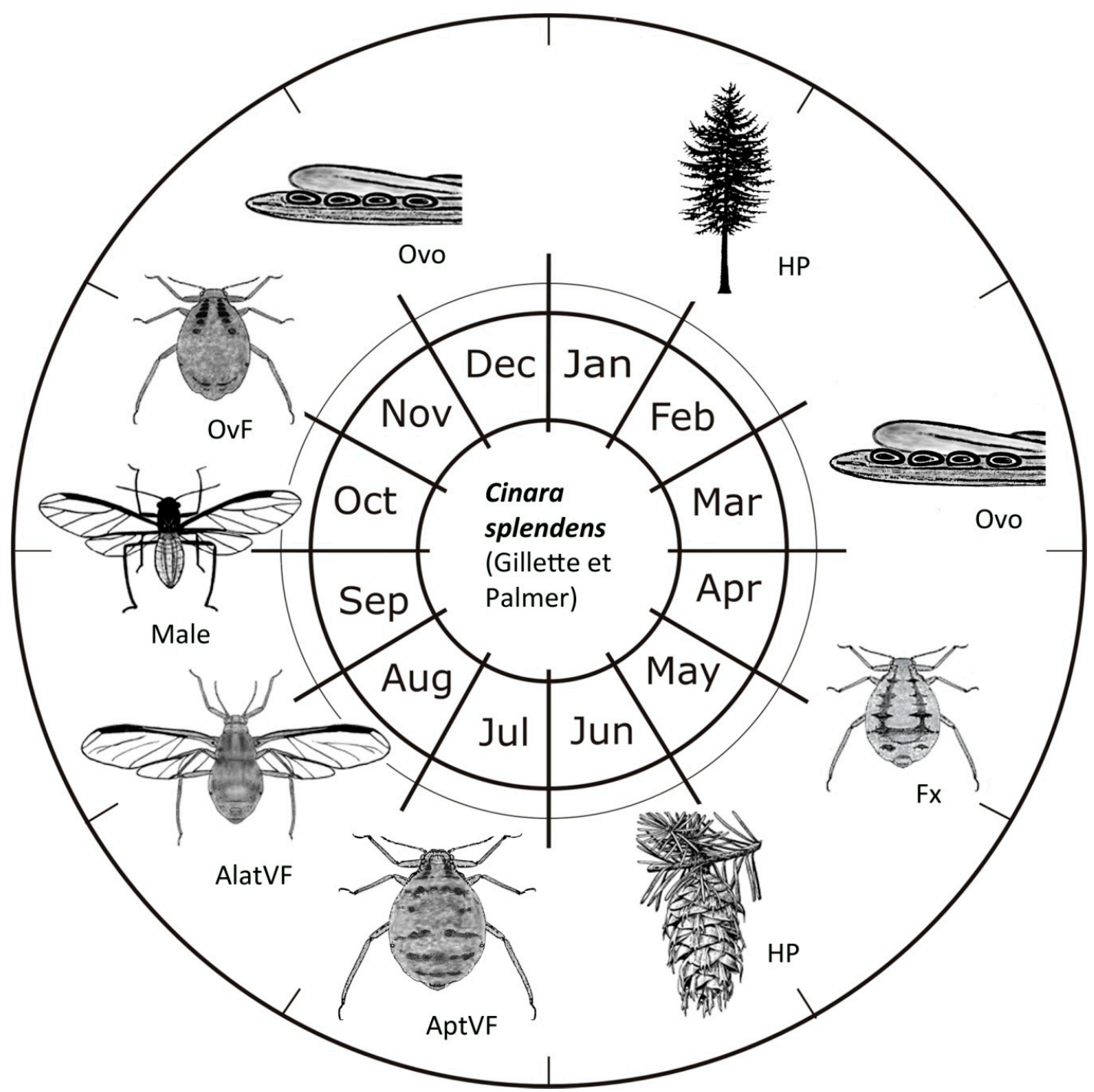

Figure 3. Cinara splendens (Gillette and Palmer, 1924) life-cycle in Central Europe. (HP = host plant; $\mathrm{Fx}=$ fundatrix; $\mathrm{AptVF}=$ apterous viviparous female; $\mathrm{AlatVF}=$ Alate viviparous female; OvF = ovipara).

Morphology-based identification was confirmed by the analysis of two DNA fragments, mitochondrial COI and nuclear EF-1 $\alpha$, of the collected samples. Additional partial sequences of COI $(n=29)$ and EF-1 $\alpha(n=27)$ genes were downloaded from GenBank for comparison (Table 2). Neighbor-joining (NJ) trees for both fragments were constructed to examine the position of the Cinara sample collected on Pseudotsuga in the Czech Republic among available different taxa of Cinara, feeding on the same host plant. In both cases, the sample from the Czech Republic clustered together with partial COI or EF-1 $\alpha$ sequences obtained from samples identified as C. splendens. The most similar COI haplotype to that detected in the Czech Republic was from the sample collected in Washington (USA). In the case of the EF-1 $\alpha$ fragment, the closest sequence was that originating from Oregon (USA). NJ trees are presented in Figures 4 and 5. 


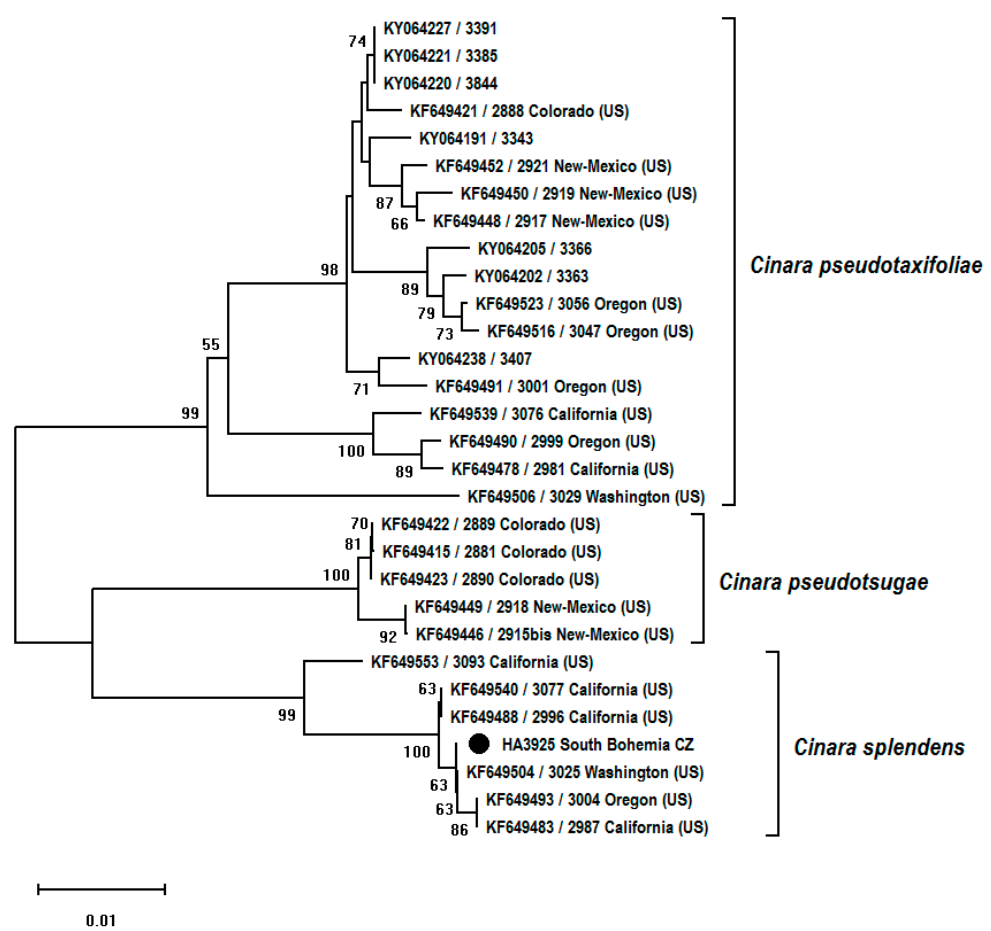

Figure 4. Neighbor-joining tree (p-distances, 1000 bootstrap replications) based on COI fragment (658 bp) of species of the genus Cinara collected from Pseudotsuga spp. Bootstrap values over 50\% are shown next to branches. The sample from the Czech Republic is marked with a black circle.

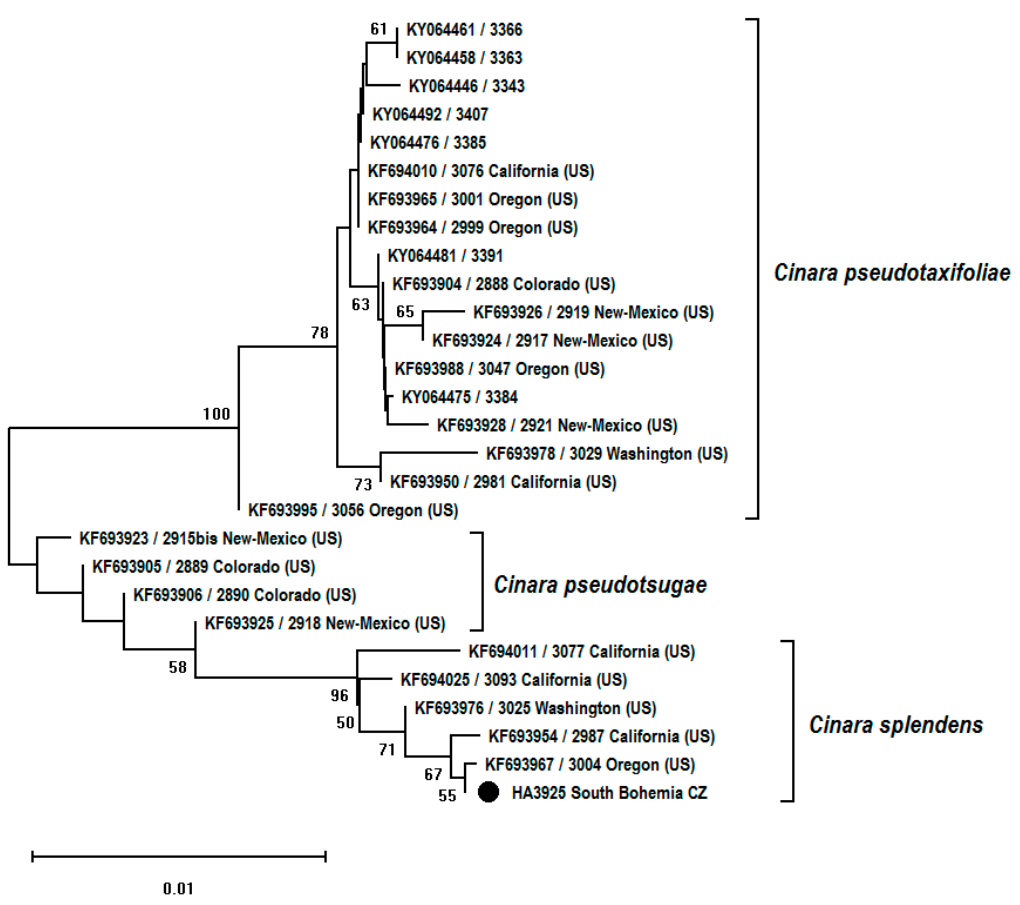

Figure 5. Neighbor-joining tree (p-distances, 1000 bootstrap replications) based on EF-1 $\alpha$ fragment (1024 bp) of species of the genus Cinara collected from Pseudotsuga spp. Bootstrap values over 50\% are shown next to branches. The sample from the Czech Republic is marked with black circle.

The native range of C. splendens is the Nearctic region, USA (Colorado), and Canada (British Columbia). In Central Europe, fundatrices occur in the April-May period. It is a monophagous species on $P$. 
menziesii, feeding mostly on the bark of 1-year-old twigs at the tips of the branches just below the buds. In the summer, it produces differently sized colonies between the needles on young twigs, often in the community with adelgids of the genus Gilletteella. They are not attended by ants. Alatae males and oviparae appear on the young twigs in late October and during November (Figure 3). After mating, oviparous females lay their glossy, coffee-dark brown eggs in small groups on the needles of host plants (Figure 2).

The principle species of predators in the Czech Republic were those from the family Coccinellidae (Coleoptera): Harmonia axyridis (Pallas, 1773), Coccinella septempunctata Linnaeus, 1758 and Aphidecta obliterata (Linnaeus, 1758). The hover flies (Diptera: Syrphidae), Syrphus ribesii (Linnaeus, 1758) and Episyrphus balteatus (De Geer, 1776) were less abundant. Aphidiid Pauesia sp. (Braconidae, Aphidiinae) was also reported by Smith [23] as a parasitoid of Cinara species, closely related to C. splendens in the USA.

\section{Discussion}

The nearctic aphid C. splendens was found in South Bohemia (the Czech Republic) in 2009. A thick layer of wax on the body of virginogenous parthenogentic females of the C. splendens, its presence in dense colonies of G. coweni, as well as the absence of ants, is probably the main reason why this rather large aphid escapes the attention of forest entomologists in Europe. Aphids of this species are very similar to those of C. pseudotaxifoliae and C. pseudotsugae, differing in the color of the hind tibia, which is pale in C. splendens and dark over the distal third or more in the other two species.

This exotic aphid species survived successfully under new ecological conditions, but its population density remained quite low. It belongs to the second group of alien aphid species (Havelka, Starý, in prep). These exotic species survive in a new place, but in normal abiotic conditions they do not cause damage to cultural plants.

Higher population density of C. splendens occurred in 2009 and 2019, only due to a synergistic effect of the dry weather and the presence of dense G. coweni colonies, which is a key pest of Douglas fir in the Czech Republic. Under those conditions, slight damage of P. menziesii, including needle yellowing and falling, has been evident. High population density was usually reduced by polyphagous predators. Coccinellid beetles were the principal predator species, while the aphidophagous hover flies were less abundant. Cinara splendens is a typical representative of the K-strategy species, which are characterized by a continuous presence in its locality at low population density and low reproduction rate. Together with a weak ability to migrate due to a low number of alate viviparous females in the population, this exotic aphid species cannot be a potential pest of $P$. menziesii in Central Europe. Honeydew of $C$. splendens is not collected by Hymenoptera and has therefore no importance as a source of honey for beekeeping. For comparison, another Nearctic species of the genus Cinara, C. curvipes, may be an example of an R-strategy exotic aphid species in Europe, as it has a wide range of host plants, disperses as aerial plankton, forms vast colonies with a large proportion of winged morphs, has a small number of natural enemies and may reproduce anholocyclically during a "warm" winter season [5].

In general, it appears that C. splendens will have not great economic importance in Central Europe. Theoretically, however, the geographical isolation of an exotic species in a new environment can cause unexpected qualitative changes [21].

\section{Conclusions}

Nearctic aphid C. splendens was discovered on ornamental Douglas fir in South Bohemia in 2009. It was the first record of this species in the Palaearctic region. After a decade of observation, it was proved that C. splendens was able to overwinter as egg and reproduce successfully on its host tree throughout the growing season in the new environment. The study of its bionomy showed that this monophagous aphid species had low ability to migrate and low population density, which was also reduced by local predators, three species of Coccinellidae (Coleoptera) and two species of Syrphidae (Diptera). During the decade of observations, there were only two population explosions of C. splendens caused 
by a synergistic effect of dry weather and high population density of adelgid G. coweni, a key pest of Douglas fir in Czech Republic. The honeydew produced by C. splendens is not collected by ants, bees and other Hymenoptera, therefore, this aphid species has no influence on beekeeping as a potential source of honey. In general, it appears that $C$. splendens will have not great economic importance in Central Europe.

Supplementary Materials: The following are available online at http://www.mdpi.com/1999-4907/11/9/911/s1, Table S1: General morphometric data of Cinara splendens samples from Czech Republic.

Author Contributions: Investigation, J.H. (Jan Havelka), J.H. (Jekaterina Havelka) and P.S.; Writing—original draft, J.H. (Jan Havelka); Writing_review \& editing, J.H. (Jan Havelka), J.H. (Jekaterina Havelka) and P.S. All authors have read and agreed to the published version of the manuscript.

Funding: This research was funded by the Institute of Entomology, Biology Centre of Czech Academy of Sciences, grant number Z50070508; and the Research Council of Lithuania, grant number P-MIP-17-365.

Acknowledgments: The technical assistance of Vera Chalušová and Jana Stará (Institute of Entomology, České Budějovice, Czech Republic) is highly appreciated.

Conflicts of Interest: The authors declare no conflict of interest.

\section{References}

1. Mlíkovský, J.; Stýblo, P. Nepuivodní druhy fauny a flóry ČR; ČSOP: Praha, Czech Republic, 2006; 495p.

2. Petrović-Obradović, O.; Tomanović, Ž.; Poljaković-Pajnik, L.; Vučetić, A. An invasive species of aphid, Prociphilus fraxinifolii (Hemiptera, Aphididae, Eriosomatinae), found in Serbia. Arch. Biol. Sci. Belgrade 2007, 59, 9-10. [CrossRef]

3. Petrović-Obradović, O.; Tomanović, Ž.; Poljaković-Pajnik, L.; Hrnčić, S.; Vučetić, A.; Radonjić, S. New invasive species of aphids (Hemiptera, Aphididae) in Serbia and Montenegro. Arch. Biol. Sci., Belgrade 2010, 62, 775-780. [CrossRef]

4. Junkiert, Ł.; Wieczorek, K.; Wojciechowski, W. Periphyllus californiensis Shinji, 1917 (Hemiptera: Aphidoidea)—An invasive aphid species new to Poland. Pol. J. Entomol. 2011, 80, 3-12. [CrossRef]

5. Hałaj, R.; Osiadacz, B. On foreign land: The conquest of Europe by Cinara curvipes (Patch, 1912). Dt. Entomol. Z. 2015, 62, 261-265. [CrossRef]

6. Kanturski, M.; Lee, Y.; Depa, Ł. New records of an alien aphid species Tinocallis (Sappocallis) takachihoensis from countries in central and northern Europe (Hemiptera, Aphididae, Calaphidinae). ZooKeys 2018, 730, 1-17. [CrossRef] [PubMed]

7. Danilov, J.; Havelka, J.; Rakauskas, R. New for Lithuania aphid species of the tribe Eulachnini (Hemiptera: Aphididae, Lachninae): Is there any threat to local coniferous forests? Balt. For. 2019, 25, 25-31. [CrossRef]

8. Wieczorek, K.; Chłond, D. Description of the previously unknown sexual morphs of Eucarazzia elegans from Iran and Pakistan and the northernmost record of viviparous generation from Europe. Bull. Insectol. 2019, 72, 177-186.

9. Brandl, H. Erganzende untersuchungen zur ertragslage der baumarten fichte, kiefer, buche und eiche in Baden-Württemberg. Allg. Forst Jagdztg. 1989, 160, 91-99.

10. Heidingsfelder, A.; Knoke, T. Douglasie versus Fichte; J.D. Sauerländer's Verlag: Frankfurt, Germany, 2004.

11. Hanewinkel, M. Klimawandel: Arealverschiebung von Hauptbaumarten in Südwest Deutschland. Available online: http://www.waldwissen.net (accessed on 8 February 2010).

12. Schwappach, A. Denkschrift betreffend die Ergebnisse der in den Jahren 1981 bis 1890 in den PreuBischen Staatsforsten ausgef Uhrten Anbauversuchen mit fremdlandischen Holzarten. Z. Forst Jagdwes. 1891, 23, 18-34, 81-102, 148-164.

13. Kandler, G.; Schmidt, M.; Breidenbach, J. Der Wald in Baden-Württemberg-Ergebnisse der Bundeswaldinventur 2. Available online: www.fva-bw.de/forschunglindex2.html (accessed on 8 February 2010).

14. Podrázský, V.; Kubeček, J.; Čermák, R.; Štefančík, I. Zhodnocení dosavadního výzkumu douglasky tisolisté v České republice-přehled. In Proceedings of the Central European Silviculture, Kostelec nad Černými lesy, Czech Republic, 2-3 July 2013; Baláš, M., Podrázský, V., Kučeravá, B., Eds.; ČZU: Praha, Czech Republic, 2013; pp. 192-203. 
15. Palmer, M.A. Aphids of the Rocky Mountain Region; Thomas Say Foundation; Hirschfeld Press: Denver, Colorado, 1952; Volume 5, 452p.

16. Blackman, R.L.; Eastop, V.F. Aphids on the World's Trees: An Identification and Information Guide; CAB International: Oxon, UK, 1994.

17. Folmer, O.; Black, M.; Hoeh, W.; Lutz, R.; Vriehoek, R. DNA primers for amplification of mitochondrial cytochrome C oxidase subunit I from diverse metazoan invertebrates. Mol. Mar. Biol. Biotechnol. 1994, 3, 294-299. [PubMed]

18. von Dohlen, C.D.; Kurosu, U.; Aoki, S. Phylogenetics and evolution of the eastern Asian eastern North American disjunct aphid tribe, Hormaphidini (Hemiptera: Aphididae). Mol. Phylogenet. Evol. 2002, 23, 257-267. [CrossRef]

19. Hall, T.A. BioEdit: A user-friendly biological sequence alignment editor and analysis program for Windows 95/98/NT. Nucl. Acids Symp. 1999, 41, 95-98.

20. Kumar, S.; STecher, G.; Tamura, K. MEGA7: Molecular Evolutionary Genetics Analysis version 7.0 for bigger datasets. Mol. Biol. Evol. 2016, 33, 1870-1874. [CrossRef] [PubMed]

21. Jousselin, E.; Cruad, A.; Genson, G.; Chevenet, F.; Fottitt, R.G.; Coeur d'Acier, A. Is ecological speciation a major trend in aphids? Insights from a molecular phylogeny of the conifer-feeding genus Cinara. Front. Zool. 2013, 10, 56. [CrossRef] [PubMed]

22. Meseguer, A.; Manzano-Marin, A.; Coeur d'Acier, A.; Clamens, A.-L.; Godefroid, M.; Jousselin, E. Buchnera has changed flatmate but the repeated replacement of co-obligate symbionts is not associated with the ecological expansions of their aphid hosts. Mol. Ecol. 2017, 26, 2363-2378. [CrossRef] [PubMed]

23. Smith, J. Differential growth of roots and shoots of Douglas-fir (Pseudotsuga menziesii) seedlings infested with Cinara pseudotsugae, and population dynamics of a parasitoid wasp (Pauesia sp.) of C. splendens. Master's Thesis, Oregon State University, Corvallis, OR, USA, 1997.

(C) 2020 by the authors. Licensee MDPI, Basel, Switzerland. This article is an open access article distributed under the terms and conditions of the Creative Commons Attribution (CC BY) license (http://creativecommons.org/licenses/by/4.0/). 